\title{
Effect of chitosan-carvacrol edible coatings on the quality and shelf life of tilapia (Oreochromis niloticus) fillets stored in ice
}

\author{
Saraí CHAPARRO-HERNÁNDEZ1 ${ }^{1}$, Saúl RUÍZ-CRUZ ${ }^{1 *}$, Enrique MÁRQUEZ-RÍOS², \\ Víctor Manuel OCAÑO-HIGUERA ${ }^{3}$, Carla Cecilia VALENZUELA-LÓPEZ ${ }^{1}$, \\ José de Jesús ORNELAS-PAZ ${ }^{4}$, Carmen Lizette DEL-TORO-SÁNCHEZ²
}

\begin{abstract}
Fish consumption has increased in recent years. However, fish meat is highly perishable, which demonstrates the need for technologies to preserve its quality. Edible coatings (EC) might provide an alternative to extend the shelf life of fish. The goal of this study was to evaluate the effect of EC of chitosan (C) in combination with carvacrol (CAR) on the physical and microbiological changes of tilapia fillets. Fillets were submerged for two minutes in different treatments (T1: control; T2: C 2\%; T3: C 2\% + 0.125\% CAR; T 4: C 2\% + 0.25\% CAR). At the end of storage, T1 and T2 showed the lowest values of total volatile bases (TVB). The color parameters $\mathrm{L}^{*}, \mathrm{a}^{*}$ and $\mathrm{b}^{*}$ varied from each treatment. The texture decreased and the different treatments reduced the microbial population in relation to the control; T3 and T4 were the most effective. These results show that the use of $\mathrm{C}$ with CAR might be an alternative method to preserve the quality and safety of tilapia fillets.
\end{abstract}

Keywords: chitosan; essential oils; edible coating; tilapia fillets.

Practical Application: The use edible coatings of chitosan-carvacrol could be an alternative to preserve the quality and increase the shelf-life of tilapia fillets.

\section{Introduction}

Fish consumption has been increasing due to the nutrients it contains and its benefits for human health and the prevention of wide variety of diseases (Babcock et al., 2000; Carrero et al., 2005). Tilapia fish is the second most common product obtained by fishing. In Mexico it is consumed fresh, and its most common market presentation is fresh in ice (Sagarpa-Conapesca, 2011). However, fish meat is a highly perishable food because it undergoes both physical and biochemical post-mortem alterations that modify its sensory characteristics; additionally, the nutrients it contains make it suitable for microbial growth (Gram \& Huss, 1996; Sallam, 2007).

Under ideal conditions of post capture handling, shelf life of fish products is mainly determined by endogenous biochemical reactions. However, due to the poor post-harvest handling, they deteriorate by microbial action. So, the inhibition or microbial growth delay is one of the most frequent actions in the handling and processing of fishery products (Márquez-Rios et al., 2007). In this sense, some alternatives have been sought for its preservation. Among these alternatives is the addition of salt (Chaijan, 2011; Hong et al., 2012) as well as the application of edible coatings (ECs). Some coatings are supplemented with antimicrobial agents that retard deterioration and maintain freshness, showing great potential for application in preserving fresh fish fillets (Jeon et al., 2002; Iturriaga et al., 2012). Coverings and coated films could be produced from different materials such as lipids, proteins, and polysaccharides or combinations of these materials. However, polysaccharides are the most commonly used materials. Chitosan is a polymer derived from chitin, which is obtained from shells of shrimp. Its characteristics make it suitable for use in coatings because it exhibits good gel formation and is not toxic for human consumption (Sinha et al., 2004; Rajaakshmi et al., 2013).

Due to the high consumption of tilapia in México and elsewhere in the world, this research has focused on increasing the shelf life of this highly perishable food product, through the inhibition of microbial deterioration. Therefore, the objective of the present study was to evaluate the effect of chitosan-based ECs with added essential oils on the physical, biochemical, and microbiological changes of tilapia fillets stored on ice to increase its shelf life.

\section{Materials and methods}

\subsection{Raw material}

Specimens of tilapia were bought at the SANAGRO's tilapia farm located in San Pedro de la Cueva, Sonora. The fish were stored in a hermetically sealed cooler, properly iced by alternating layers of ice and fish, and taken to the Laboratory for Management and Processing of Seafood at the University of Sonora, where they were filleted and stored for later use. 


\subsection{Chitosan}

Chitosan was obtained using the methodology described by Khanafari et al. (2008), with some modifications.

\subsection{Preparation and application of EC}

Emulsions were prepared by dissolving $2 \%$ chitosan in $10 \%$ acetic acid. Glycerol (1.5\%) was added as a plasticizer, and Tween 80 was added as a surfactant. Later, essential oil (carvacrol) at concentrations of 0.125 and $0.25 \%$ was added. The solution was homogenized at 12,500 rpm (Rojas-Grau et al., 2007). Finally, tilapia fillets were immersed for two min in this solution.

\subsection{Evaluation of fillet quality and shelf life}

Once the coatings were applied, the tilapia fillets were wrapped in plastic bags and stored in ice for 21 days. At three-day intervals, samples for physical, biochemical, and microbiological analyses were taken.

\subsection{Biochemical analyses}

Total volatile bases (TVBs)

Samples (2 g) were mixed with $300 \mathrm{~mL}$ of distilled water. Then, $2 \mathrm{~g}$ of magnesium oxide and $25 \mathrm{~mL}$ of commercial oil were added as defoamers. The sample was heated to the boiling point and allowed to distill for $25 \mathrm{~min}$. The distilled liquid was recovered in an Erlenmeyer flask with $15 \mathrm{~mL}$ of $2 \%$ boric acid, which was titrated with a solution of $0.05 \mathrm{~N} \mathrm{H}_{2} \mathrm{SO}_{4}$. The TVBs were expressed as $\mathrm{mg}$ of N/100 g sample (Woyewoda et al., 1986).

\subsection{Physical analyses}

$p H$

Muscle $\mathrm{pH}$ was determined based on the method described by Woyewoda et al. (1986) using a digital $\mathrm{pH}$-meter (CORNING model 240, New York, USA).

\section{Color measurement}

Changes in fillet colors were determined by tristimulus colorimetry using Minolta equipment (Model CR-300, Minolta Co., New York, NY.). Measurements were taken on both surfaces of the fillet (white and red regions) to obtain the color parameters $\mathrm{L}^{*}, \mathrm{a}^{*}$, and $\mathrm{b}^{*}$.

\section{Texture}

Shear force $(\mathrm{N})$ was determined using a Warner-Bratzler cell at a speed of $20 \mathrm{~cm} / \mathrm{min}$ in a Lab Pro texturometer (Food Technology Corp., Sterling, VA). Fillets $(10 \mathrm{~mm} \times 10 \mathrm{~mm} \times 20 \mathrm{~mm})$ were cut, and a transverse force to the direction of the muscle fibers was applied.

\section{Water retention capacity (WRC)}

The WRC of fillet was determined based on the method described by Cheng et al. (1979). $5 \mathrm{~g}$ of fillet were centrifuged at $28,000 \mathrm{~g}$ for $30 \mathrm{~min}$ at $4{ }^{\circ} \mathrm{C}$, using a refrigerated centrifuge
(Beckman J2-21 model, Beckman Instruments Inc. Palo Alto, CA). The WRC was expressed as the loss of water with respect to the initial content (\%).

\subsection{Microbiological analyses}

Counting and differentiation of each microorganism type was performed using the following media and culture conditions: total aerobic count were measured according to the methodology established by NOM-092-SSA1-1994 (Norma Oficial Mexicana, 1994a), in which the plate count agar (PCA) procedure was performed; the total coliforms were determined in red-violet bile agar, according to NOM-112-SSA1-1994 (Norma Oficial Mexicana, 1994b); the amount of Vibrio spp. were quantified using the methodology described by NOM-029-SSA1-1993 (Norma Oficial Mexicana, 1993a). The plates were incubated at $37^{\circ} \mathrm{C}$ by $24-48 \mathrm{~h}$.

\subsection{Experimental design and statistical analysis}

The experiment was performed by applying a randomized complete block design in which days of sampling was considered a block and treatments applied to fillets (composition of coatings) were factors. The results are expressed as mean values $\pm \mathrm{SD}$, and statistical significance was set at the 5\% level $(p<0.05)$. The Tukey-Kramer test was used to determine differences between the treatments of every storage time using the Statgraphics Plus v. 5.0 software.

\section{Results and Discussion}

\subsection{TVBs}

TVBs are commonly used as indicators of meat deterioration and increase according to microbial and enzymatic spoilage (Fan et al., 2009). The initial TVB value was $31.237 \mathrm{mg} / 100 \mathrm{~g}$, which showed a variable behavior during the storage period. At the end of storage, the values were between 27.06 and $31.42 \mathrm{mg} / 100 \mathrm{~g}$ (Figure 1). We observed that the values for T3 and T4 were higher than the control value, whereas the $\mathrm{T} 2$ value did not

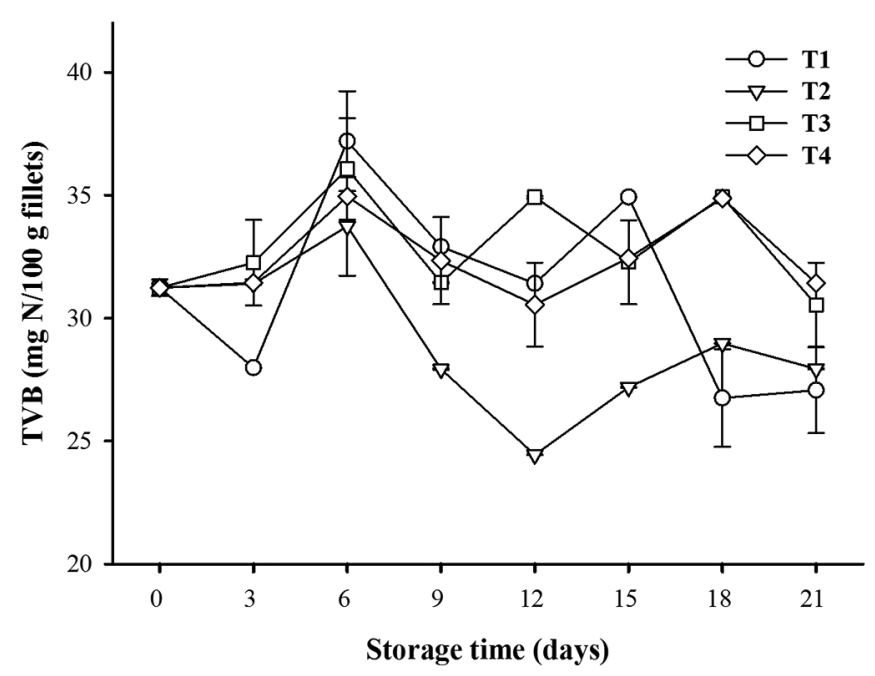

Figure 1. Effect of chitosan-carvacrol coatings on the content of total volatile bases in tilapia fillets stored in ice. 
show a significant difference compared to the control value $(p>0.05)$. These values are higher than those reported by Ahmad et al. (2012), where the TVB values in bass slices covered with a gelatin film and with gelatin plus lemon grass oil showed an initial value of $12.47 \mathrm{mg} / 100 \mathrm{~g}$ and final values of 18.34 and $15.84 \mathrm{mg} / 100 \mathrm{~g}$, respectively. Gómez-Estaca et al. (2010) applied a film of chitosan and gelatin to cod and, after 12 days of storage, recorded 13.5 and $40 \mathrm{mg} / 100 \mathrm{~g}$ for initial and final values, respectively. It is known that TVB values increase due to autolytic and microbial deterioration that occurs in the fillet (Özogul \& Özogul, 2002); additionally, because TVBs determine the levels nitrogen-derived compounds during fish decomposition (Fan et al., 2009), the area of origin or the food received at the farm from which the samples were obtained for this study might be the cause of the high TVB values obtained at the outset. However, the decrease in TVB values could be due to the possible leaching of these compounds, mainly ammonia, caused by contact with melted ice during the storage period (Etienne, 2005). The results shown that microbial growth in tilapia fillets did not contribute to increased TVB. It could be attributed to acid surface in fillets, because of chitosan was dissolved in acetic acid. It is probably that acid environment difficult the enzymatic production of TVB by microorganism.

\subsection{Physical analyses}

$p H$

The initial $\mathrm{pH}$ in muscle may vary once the fish is dead. This variation will depend on the form of capture, season, species, diet, and stress level, among other factors (Rong et al., 2009;
Ocaño-Higuera et al., 2009). After the initial decrease, $\mathrm{pH}$ tends to neutralize due to reactions that occur after death. The initial $\mathrm{pH}$ value in this study was 6.2 (Table 1). A slight increase was observed in the control during storage, which reached a final value of 6.7, while the treatments T2, T3 and T4 showed final values of $6.21,6.11$, and 6.10 , respectively. No significant differences were observed between T2, T3 and T4 $(p>0.05)$, but these values were significant with respect to the control (T1). Similar results have been reported by Gómez-Estaca et al. (2010), who found that the $\mathrm{pH}$ did not increase in cod when a gelatin-chitosan coating was applied, reaching a value of $7 \mathrm{after}$ an initial value of 6.7. In addition, Soto-Valdez et al. (2015) reported $\mathrm{pH}$ values initial and final of 6.3 and 6.5 in sierra fish fillets packed in a low-density polyethylene film containing butylated hydroxytoluene and stored 16 days in ice. However, Mohan et al. (2012) applied 1 and 2\% chitosan coatings to frozen-stored sardines and reported $\mathrm{pH}$ values of 6.84 and 6.51, respectively, which were higher than the control value (6.48). Both studies coincide with the findings of the present study. However, Fan et al. (2009) observed the effect on the $\mathrm{pH}$ of carp fillets stored frozen with a gelatin-chitosan coating applied, with initial and final $\mathrm{pH}$ values of 6.0 and 7.5 , respectively, which are higher than those obtained in the present study. The sudden $\mathrm{pH}$ decrease in this study might be due to the production of lactic acid in the muscle (not determined) (Márquez-Ríos et al., 2011). However, this response might also be affected by the application of coatings, as they contain acetic acid (Tsai et al., 2003; López-Caballero et al., 2005; Gómez-Estaca et al., 2010). The $\mathrm{pH}$ behavior, almost constant during the storage, could be associated to TVB, which did not show a significant increased

Table 1. Effect of chitosan-carvacrol coatings on physicochemical parameters of tilapia fillets stored in ice.

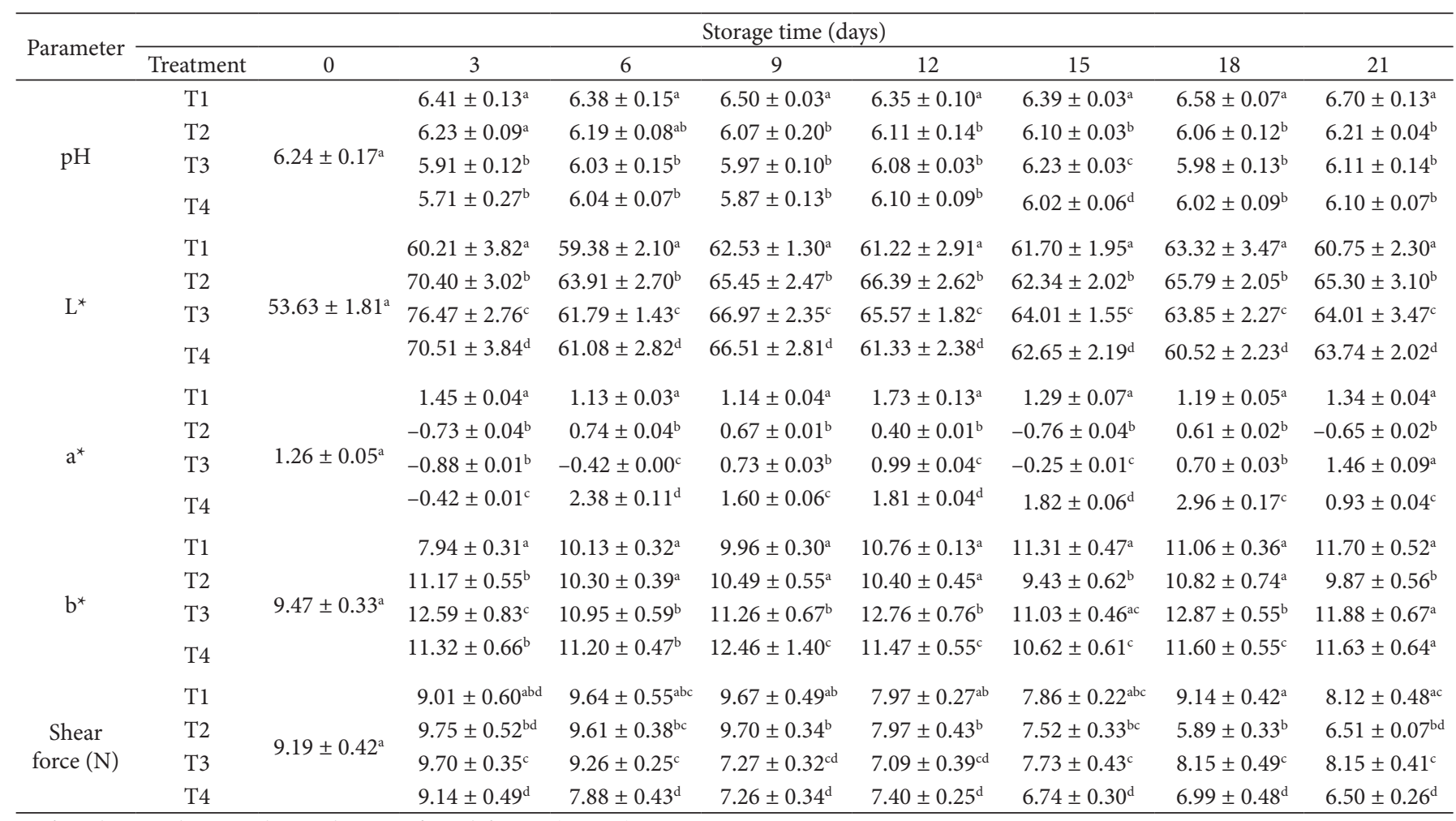

Different letters in the same column indicate significant differences $(P<0.05)$ among treatments. 
during the experiment. It is known that the $\mathrm{pH}$ increased is well related to TVB increased (Castillo-Yañez et al., 2007).

Color

The values of $L^{*}$ obtained in tilapia fillets range between 53.63 (initial value) and 60.75, 65.309, 64.01 and 63.74 (final values) for T1, T2, T3 and T4, respectively (Table 1). These values are higher than those observed by Mohan et al. (2012), where a decrease in brightness values was reported in sardine fillets treated with $1 \%$ and $2 \%$ chitosan, with initial values of 54.21 and 54.18 ; at day 9, those values were reduced to 43.17 and 47.11 , respectively, but were still higher than the control value (41.18). However, Ocaño-Higuera et al. (2009) observed an increase in $b^{*}$ in dogfish muscles, from 45.7 to 47 on day 18 during storage in ice. Similarly, Veeck et al. (2013) reported an increase in brightness as frozen storage time increased. This result may be due to the oxidation of proteins, which could change light reflectance and produce a direct impact on brightness (Mørkøre, 2006). The high values of $L^{\star}$ for samples treated with chitosan may be due to the low $\mathrm{pH}$ of the chitosan solution used, which produces leaching of muscle pigments during treatment (Mohan et al., 2012).

The initial $\mathrm{a}^{*}$ and $\mathrm{b}^{\star}$ values were 1.265 and 9.4737 , respectively (Table 1). A slight increase in $\mathrm{a}^{*}$ was observed in T1 (1.3475) and T3 (1.4614), whereas in T2 (-0.65) and T4 (0.9383), $\mathrm{a}^{\star}$ decreased. An increase in the $b^{*}$ parameter was found in all treatments evaluated; the greatest increase was shown in T3 (11.88), followed by T1 (11.7076), T4 (11.6392), and T2 (9.87286). Mohan et al. (2012) reported values for $\mathrm{a}^{*}$ of $10.09-8.32$ and 10.13-8.41 and for $\mathrm{b}^{*}$ of 18.34-16.01 and 18.28-16.38 in sardines treated with chitosan EC at 1 and $2 \%$, respectively. In both cases, the values were higher than those of the control, with values of $\mathrm{a}^{*}$ of 7.01 and $b^{*}$ of 14.18. Ocaño-Higuera et al. (2009) reported $\mathrm{a}^{*}$ and $\mathrm{b}^{*}$ values of $0.69-4$ and $0.94-3.5$, respectively, in dogfish muscles (without coating). Those values are similar to the values of our present study. These parameters might be affected by the oxidation of compounds found in muscle (Mohan et al., 2012). When values of $\mathrm{a}^{\star}$ and $\mathrm{b}^{\star}$ are low, it indicates that the product is opaque (Ocaño-Higuera et al., 2011). The fillet samples were within the yellow-red zone at the start of the study, and by the end of the study, the T2 group was slightly within the yellow-green zone. The rest of the treatments were within the initial zone (yellow-red). All samples showed an increase in brightness, indicating that the samples were closer to white.

\section{Texture}

The softening that occur post-mortem is one of the factors that should be avoided during storage, as it affects the organoleptic acceptability sought by consumers. The initial texture value was 9.19 N, which decreased to 8 (T1 and T3) and 6.5 (T2 and T4) to final storage time (Table 1). A rapid decline was observed in T4, on day 6. These are higher values than those obtained by Alasalvar et al. (2001) in bream fillets, with values between 7.5 and $5 \mathrm{~N}$ during 17 days of storage. On the other hand, Valencia-Perez et al. (2015) observed a similar diminution of texture in blue shrimp treated with antioxidants and packed in a bilayer film of polyamide-low density polyethylene film with $2 \%$ a-tocopherol during frozen storage. A similar finding was observed by Ocaño-Higuera et al. (2009), with approximate values of 7.2 to $5 \mathrm{~N}$ in dogfish muscle on day 18 of storage. Mohan et al. (2012) reported lower final texture values (initial $4.73 \mathrm{~N}$, final $1.89 \mathrm{~N}$ ) in sardine fillets treated with 1 and $2 \%$ chitosan coating. Texture loss could be due to natural deterioration suffered by proteins due to water loss in the muscle as well as to degradation by microbial action and endogenous proteolytic activity (Suárez-Mahecha et al., 2007; Pacheco-Aguilar et al., 2008).

\section{Water retention capacity}

When a fish fillet is fresh, its WRC is very high, and it decreases as deterioration progresses. Figure 2 shows the effect of treatments on WRC in tilapia fillets, which shows a variable behavior. A noticeable decrease is observed on day 3 in T2 (90.32\%) and T4 (89.87\%), although the value increases later. The previous could be attributed to decreased muscle $\mathrm{pH}$, associated to lactic acid accumulation (Castillo-Yañez et al., 2007). Mohan et al. (2012) reported that sardines with 1 and $2 \%$ chitosan coatings showed greater WRC than the controls, with initial values of 18.31 and final values of 14.71 and $16.51 \%$, respectively, whereas the final control value was $9.83 \%$. The variability in those values and the increase in the last days of our study might be due to rigor mortis in muscle, during which WRC is very low but later increases (Huss, 1988). Another possible factor responsible for the variability may be the polarity of the polymer, as usually greater polarity is associated with lower porosity and water loss (Jeon et al., 2002; Mohan et al., 2012); the incorporation of carvacrol also produces a more compact network (López-Mata et al., 2013).

\subsection{Microbiological analyses}

The different treatments applied reduced the population of aerobic mesophilic microbes by 2 Log UFC/g per day (Figure 3 ). An increase during storage was observed, at the end of which a population of between 2.9 and $6.4 \mathrm{Log} \mathrm{UFC} / \mathrm{g}$ was reached. $\mathrm{T} 2$, T3, and T4 caused a reduction of $2.4,3.5$, and 3.5 Log UFC/g, respectively, compared to the control. The values obtained with

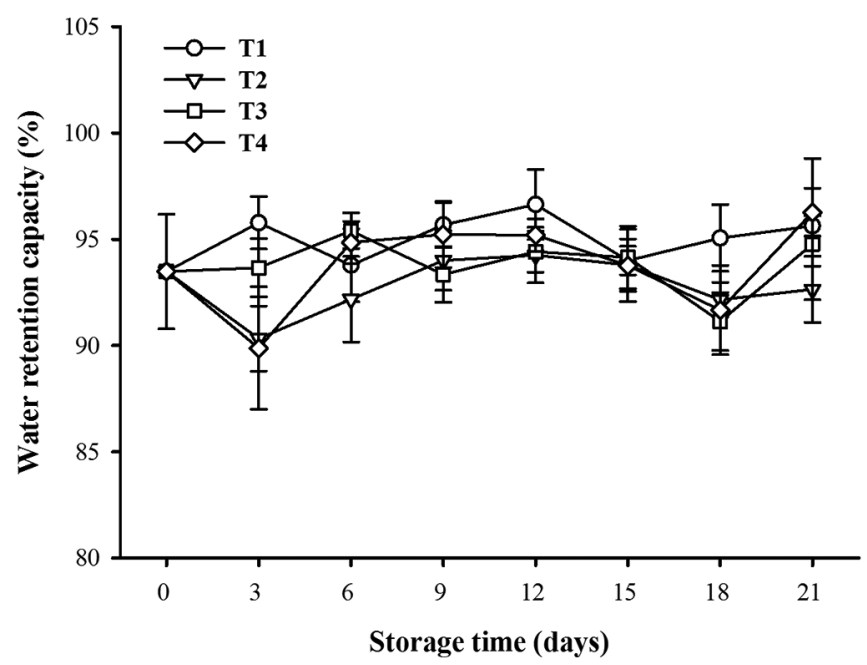

Figure 2. Effect of chitosan-carvacrol coatings on WRC in tilapia fillets stored in ice. The values are expressed as $\mathrm{mL}$ of water released after centrifugation. 
the treatments are within the maximum allowable limit for mesophilic microbes (4 Log UFC/g), according to the Official Mexican Regulation NOM-027-SSA1-1993 (Norma Oficial Mexicana, 1993b). Mohan et al. (2012) reported a reduction between 1.3 and $1.9 \mathrm{Log}$ UFC/g in sardines treated with 1 and $2 \%$ chitosan coating. Vatavali et al. (2013) reported reductions of 1.1, 1.7, and 2.2 Log UFC/g in treatments with oregano essential oil, chitosan coating, and a combination of both, respectively, applied to red snapper. Jeon et al. (2002) showed a reduction of 2 and $3 \mathrm{Log} \mathrm{UFC} / \mathrm{g}$ in cod and herring, respectively, treated with chitosan coatings. These values are lower than those found in our study.

The initial value of total coliforms was $0.2 \mathrm{Log} \mathrm{UFC} / \mathrm{g}$ (Figure 4). An increase was observed during storage, and at the end, the population varied between 1.4 and $2.4 \mathrm{Log} \mathrm{UFC} / \mathrm{g}$. The control (T1) showed the largest population, and T4 showed the smallest population, with a reduction of $1 \mathrm{Log} \mathrm{UFC} / \mathrm{g}$ with

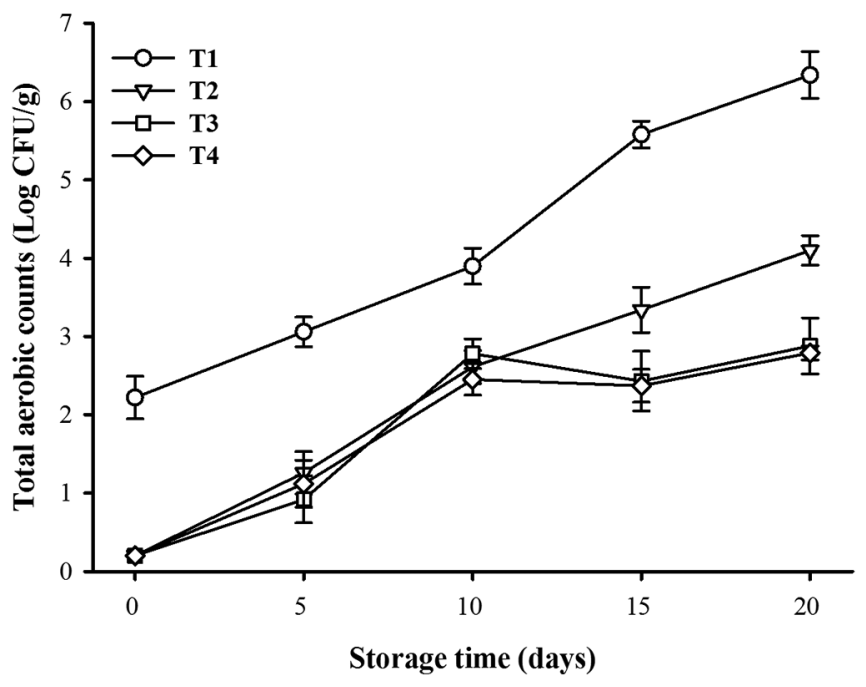

Figure 3. Effect of chitosan-carvacrol coatings on the number of total aerobic counts in tilapia fillets stored in ice.

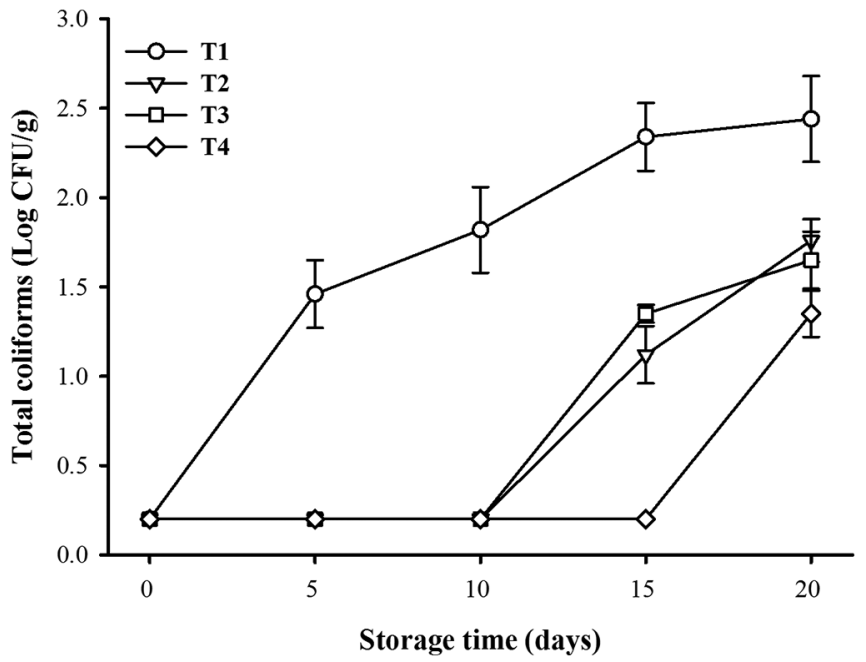

Figure 4. Effect of chitosan-carvacrol coatings on the number of total coliforms in tilapia fillets stored in ice. respect to the control. Tsai et al. (2002) obtained a $3 \mathrm{Log}$ UFC/g reduction in trout and salmon fillets by treating them with $1 \%$ chitosan coating. Vatavali et al. (2013) obtained reductions in red snapper of $0.4,1.4$, and $1.8 \mathrm{Log} \mathrm{UFC} / \mathrm{g}$ when treating them with oregano oil, chitosan, and a combination of both, respectively.

Vibrio alginolyticus populations were not detected in any of the treatments, causing a reduction of 2 Log UFC/g (100\%) with respect to the control. T3 and T4 caused reductions of 2.8 and $2 \mathrm{Log}$ UFC/g of $V$. cholerae and V. alginolyticus, respectively (Figure 5). T2 caused reductions of 1.4 and $0.7 \mathrm{Log}$ UFC/g (44 and

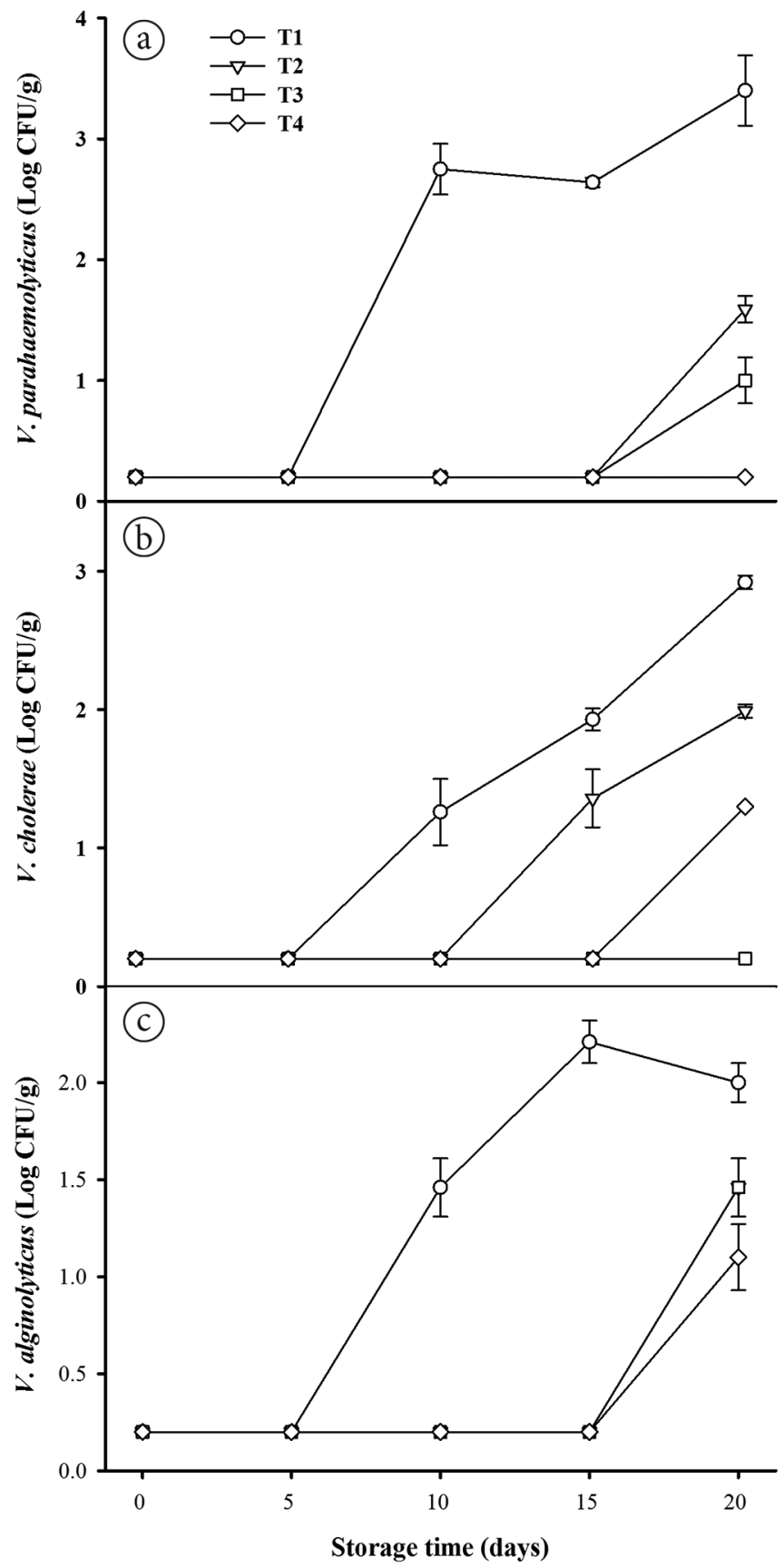

Figure 5. Effect of chitosan-carvacrol coatings on the number of colonies of (a) V. parahaemolyticus, (b) V. cholerae, and (c) V. alginolyticus in tilapia fillets stored in ice. 
$31 \%)$ of V. parahaemolyticus and cholerae, respectively. Similar results were reported by Anas et al. (2005), who applied 1\% chitosan to shrimp and found reductions of 85,69 and $50 \%$ in $V$. cholerae, V. parahaemolyticus, and V. alginolyticus, respectively. Likewise, Chaiyakosa et al. (2007) obtained reductions of 81 and $96 \%$ while applying $0.25 \%$ chitosan solutions for 10 and $30 \mathrm{~min}$, respectively, on shrimp infected with $V$. parahaemolyticus. Lower values were reported by No et al. (2002), who used $0.1 \%$ chitosan against V. parahaemolyticus and obtained a $50 \%$ reduction. In another study, Terzi \& Gucukoglu (2010) tested $0.05 \%$ chitosan for 30 min against $V$. parahaemolyticus and obtained a 33\% reduction in mussels.

\section{Conclusions}

The application of edible coating of chitosan-carvacrol appears to be a viable alternative for the conservation of tilapia fillets, as it maintains some quality parameters and reduces the microbial population associated with the deterioration of the fillets during storage in ice.

\section{Acknowledgements}

The authors gratefully acknowledge the financial support from Instituto Tecnológico de Sonora (project clave PROFAPI 00401 and 00500).

\section{References}

Ahmad, M., Benjakul, S., Sumpavapol, P., \& Nirmal, N. P. (2012). Quality changes of sea bass slices wrapped with gelatin film incorporated with lemongrass essential oil. International Journal of Food Microbiology, 155(3), 171-178. http://dx.doi.org/10.1016/j. ijfoodmicro.2012.01.027. PMid:22370476.

Alasalvar, C., Taylor, K. D. A., Öksüz, A., Garthwaite, T., Alexis, M. N., \& Grigorakis, K. (2001). Freshness assessment of cultured sea brean (Sparus aurata) by chemical, physical and sensory methods. Food Chemistry, 72(1), 33-40. http://dx.doi.org/10.1016/S03088146(00)00196-5.

Anas, A., Paul, S., Jayaprakash, N. S., Philip, R., \& Bright-Singh, I. S. (2005). Antimicrobial activity of chitosan against vibrios from freshwater prawn Macrobrachium rosenbergii larval rearing systems. Diseases of Aquatic Organisms, 67(1-2), 177-179. http://dx.doi. org/10.3354/dao067177. PMid:16385825.

Babcock, T., Helton, W. S., \& Espat, J. (2000). Eicosapentanoic Acid (EPA): An antiinflamatory $\omega-3$ fat with potential clinical applications. Nutrition, 16(11-12), 1116-1118. http://dx.doi.org/10.1016/S08999007(00)00392-0. PMid:11118844.

Carrero, J. J., Martín-Bautista, E., Baró, L., Fonollá, J., Jiménez, J., Boza, J. J., \& López-Huertas, E. (2005). Efectos cardiovasculares de los ácidos grasos omega-3 y alternativas para incrementar su ingesta. Nutricion Hospitalaria, 20(1), 63-69. PMid:15762422.

Castillo-Yañez, F. J., Pacheco-Aguilar, R., Marquez-Ríos, E., LugoSánchez, M. E., \& Lozano-Taylor, J. (2007). Freshness loss in sierra fish (Scomberomorus sierra) muscle stored in ice as affected by postcapture handling practices. Journal of Food Biochemistry, 31(1), 56-67. http://dx.doi.org/10.1111/j.1745-4514.2007.00098.x.

Chaijan, M. (2011). Physicochemical changes of tilapia (Oreochromis niloticus) muscle during salting. Food Chemistry, 129(3), 1201-1210. http://dx.doi.org/10.1016/j.foodchem.2011.05.110. PMid:25212357.
Chaiyakosa, S., Charernjiratragul, W., Umsakul, K., \& Vuddhakul, V. (2007). Comparing the efficiency of chitosan with chlorine for reducing Vibrio parahaemolyticus in shrimp. Food Control, 18(9), 1031-1035. http://dx.doi.org/10.1016/j.foodcont.2006.06.008.

Cheng, C. S., Hamann, D. D., Webb, N. B., \& Sidwell, V. (1979). Effects of species and storage time on minced fish gel texture. Journal of Food Science, 44(4), 1087-1092. http://dx.doi.org/10.1111/j.1365-2621.1979. tb03453.x.

Etienne, M. (2005). Volatile amines as criteria for chemical quality assessment: methods for chemical quality assessment. SeafoodPlus. Retrieved from http://archimer.ifremer.fr/doc/2005/rapport-6486.pdf

Fan, W., Sun, J., Chen, Y., Qiu, J., Zhang, Y., \& Chi, Y. (2009). Effects of chitosan coating on quality and shelf life of silver carp during frozen storage. Food Chemistry, 115(1), 66-70. http://dx.doi.org/10.1016/j. foodchem.2008.11.060.

Gómez-Estaca, J., López de Lacey, A., López-Caballero, M. E., GómezGuillén, M. C., \& Montero, P. (2010). Biodegradable gelatin-chitosan films incorporated with essential oils as antimicrobial agents for fish preservation. Food Microbiology, 27(7), 889-896. http://dx.doi. org/10.1016/j.fm.2010.05.012. PMid:20688230.

Gram, L., \& Huss, H. H. (1996). Microbiological spoilage of fish and fish products. International Journal of Food Microbiology, 33(1), 121-137. http://dx.doi.org/10.1016/0168-1605(96)01134-8. PMid:8913813.

Hong, H., Luo, Y., Zhou, Z., \& Shen, H. (2012). Effects of low concentration of salt and sucrose on the quality of bighead carp (Aristichthys nobilis) fillets stored at $4{ }^{\circ} \mathrm{C}$. Food Chemistry, 133(1), 102-107. http://dx.doi. org/10.1016/j.foodchem.2012.01.002.

Huss, H. H. (1988). El pescado fresco: su calidad y cambios de calidad. (FAO Documento Tecnico de Pesca, 348). Rome: FAO. Retrieved from http://www.fao.org/docrep/v7180s/v7180s00.htm

Iturriaga, L., Olabarrieta, I., \& Marañón, I. M. (2012). Antimicrobial assays of natural extracts and their inhibitory effect against Listeria innocua and fish spoilage bacteria, after incorporation into biopolymer edible films. International Journal of Food Microbiology, 158(1), 58-64. http://dx.doi.org/10.1016/j.ijfoodmicro.2012.07.001. PMid:22824340.

Jeon, Y., Kamil, J. Y. V. A., \& Shahidi, F. (2002). Chitosan as an edible film for quality preservation of Herring and Atlantic cod. Journal of Agricultural and Food Chemistry, 50(18), 5167-5178. http://dx.doi. org/10.1021/jf0116931. PMid:12188625.

Khanafari, A., Marandi, R., \& Sanatei, S. (2008). Recovery of chitin and chitosan from shrimp waste by chemical and microbial methods. Iranian Journal of Environmental Health Sciences \& Engineering, 5(1), 19-24. Retrieved from http://ijehse.tums.ac.ir/index.php/ ijehse/article/download/145/144

López-Caballero, M. E., Góamez-Guillén, M. C., Pérez-Mateos, M., \& Montero, P. (2005). A functional chitosan-enriched fish sausage treated by high pressure. Journal of Food Science, 70(3), M166-M171. http://dx.doi.org/10.1111/j.1365-2621.2005.tb07145.x.

López-Mata, M. A., Ruíz-cruz, S., Silva-Beltrán, N. P., Ornelas-Paz, J., Zamudio-Flores, P. B., \& Burruel-Ibarra, S. E. (2013). Physicochemical, antimicrobial and antioxidant properties of chitosan films incorporated with carvacrol. Molecules, 18(11), 13735-13753. http://dx.doi. org/10.3390/molecules181113735. PMid:24213653.

Márquez-Ríos, E., Castillo-Yañez, F. J., Graciano-Verdugo, A. Z., Jiménez-Ruíz, E. I., Lugo-Sánchez, M. E., Maeda-Martínez, A. N., \& Ocaño-Higuera, V. M. (2011). Impacto de las prácticas artesanales de captura y manejo postcaptura en la calidad del músculo de cazón. Interciencia, 36(9), 672-676. Retrieved from http://www.redalyc.org/ articulo.oa?id=33921204006 
Márquez-Ríos, E., Morán-Palacio, E. F., Lugo-Sánchez, M. E., OcanoHiguera, V. M., \& Pacheco-Aguilar, R. (2007). Postmortem biochemical behavior of giant squid (Dosidicus gigas) mantle muscle stored in ice and its relation with quality parameters. Journal of Food Science, 72(7), 356-362. http://dx.doi.org/10.1111/j.1750-3841.2007.00468.x. PMid:17995632.

Mohan, C. O., Ravishankar, C. N., Lalitha, K. V., \& Gopal, T. K. S. (2012). Effect of chitosan edible coating on the quality of double filleted Indian oil sardine (Sardinella longiceps) during chilled storage. Food Hydrocolloids, 26(1), 167-174. http://dx.doi.org/10.1016/j. foodhyd.2011.05.005.

Mørkøre, T. (2006). Relevance of dietary oil source for contraction and quality of pre-rigor filleted Atlantic cod (Gadus morhua). Aquaculture (Amsterdam, Netherlands), 248(1), 56-65. http://dx.doi. org/10.1016/j.aquaculture.2005.05.016.

No, H. K., Park, N. Y., Lee, S. H., \& Meyers, S. P. (2002). Antibacterial activity of chitosan and chitosan oligomers with different molecular weights. International Journal of Food Microbiology, 74(1-2), 65-72. http://dx.doi.org/10.1016/S0168-1605(01)00717-6. PMid:11929171.

Norma Oficial Mexicana. (1993a). NOM-029-SSA1: bienes y servicios. Productos de la pesca. Crustáceos frescos-refrigerados y congelados: especificaciones sanitarias. Mexico: Diario Oficial de la Federación. Retreived from http://www.salud.gob.mx/unidades/cdi/nom/029ssa29. html.

Norma Oficial Mexicana. (1993b). NOM-027-SSA1: bienes y servicios. Productos de la pesca. Pescados frescos-refrigerados y congelados: especificaciones sanitarias. Mexico: Diario Oficial de la Federación. Retreived from http://www.conapesca.sagarpa.gob.mx/work/sites/ cona/resources/LocalContent/8270/4/NOM027SSA11993.pdf.

Norma Oficial Mexicana. (1994a). NOM-092-SSA 1: bienes y servicios. Método para la cuenta de bacterias aerobias en placa. Mexico: Diario Oficial de la Federación. Retreived from http://www.salud.gob.mx/ unidades/cdi/nom/092ssa14.html.

Norma Oficial Mexicana. (1994b). NOM-112-SSA1: Bienes y servicios. Determinación de bacterias coliforms: técnica del número más probable. Mexico: Diario Oficial de la Federación. Retreived from http://www. salud.gob.mx/unidades/cdi/nom/112ssa14.html.

Ocaño-Higuera, V. M., Graciano, A. Z., Castillo-Yañez, F. J., MárquezRíos, E., \& Lugo, M. E. (2011). Manipulación y calidad de productos de la pesca. In G. A. González, R. M. Robles, M. Plascencia, M. O. Cortez, \& A. Burgos (Eds.), Nuevas tendencias en Ciencia y Tecnología de Alimentos: tópicos selectos (chap. 7, pp. 148-174). México: Editorial Trillas.

Ocaño-Higuera, V. M., Márquez-Ríos, E., Canizales-Dávila, M., CastilloYáñez, F. J., Pacheco-Aguilar, R., Lugo-Sánchez, M. E., García-Orozco, K. D., \& Graciano-Verdugo, A. Z. (2009). Postmortem changes in cazon fish muscle stored on ice. Food Chemistry, 116(4), 933-938. http://dx.doi.org/10.1016/j.foodchem.2009.03.049.

Özogul, Y., \& Özogul, F. (2002). Degradation products of adenin nucleotide in rainbow trout (Oncorhynchus mykiss) stored in ice and in modified atmosphere packaging. Turkish Journal of Zoology, 26(1), 127-130. Retreived from http://journals.tubitak.gov.tr/zoology/ issue.htm? $\mathrm{id}=393$

Pacheco-Aguilar, R., Márquez-Ríos, E., Lugo-Sánchez, M. E., GarcíaSánchez, G., Maeda-Martínez, A. N., \& Ocaño-Higuera, V. M. (2008). Postmortem changes in the adductor muscle of Pacific lions-paw scallop (Nodipecten subnodosus) during ice storage. Food Chemistry, 106(1), 253-259. http://dx.doi.org/10.1016/j.foodchem.2007.05.079.

Rajaakshmi, A., Krithiga, N., \& Jayachitra, A. (2013). Antioxidant activity of the chitosan extracted from shrimp exoskeleton. Middle- east Journal of Scientific Research, 16(10), 1446-1451. http://dx.doi. org/10.5829/idosi.mejsr.2013.16.10.12033.

Rojas-Graü, M. A., Raybaudi-Massilia, R. M., Soliva-Fortuny, R. C., Avena-Bustillos, R. J., McHugh, T. H., \& Martín-Belloso, O. (2007). Apple puree-alginate edible coating as carrier of antimicrobial agents to prolong shelf-life of fresh-cut apples. Postharvest Biology and Technology, 45(2), 254-264. http://dx.doi.org/10.1016/j. postharvbio.2007.01.017.

Rong, C., Chang-hu, X., Qi, L., \& Bang-zhong, Y. (2009). Microbiological, chemical and sensory assessment of (I) whole ungutted, (II) whole gutted and (III) filleted tilapia (Oreochromis niloticus) during refrigerated storage. International Journal of Food Science \& Technology, 44(11), 2243-2248. http://dx.doi.org/10.1111/j.1365-2621.2009.02065.x.

Sagarpa-Conapesca. (2011). Guía empresarial para el cultivo, engorda y comercialización de tilapia (mojarra). México: Comisión Nacional de Acuacultura y Pesca. Retrieved from http://www.conapesca.sagarpa.gob. $\mathrm{mx} /$ work/sites/cona/dgof/publicaciones/GuiaEmpresarialTilapia.pdf

Sallam, K. I. (2007). Chemical, sensory and shelf life evaluation of sliced salmon treated with salts of organic acids. Food Chemistry, 101(2), 592-600. http://dx.doi.org/10.1016/j.foodchem.2006.02.019. PMid:17245440.

Sinha, V. R., Singla, A. K., Wadhawan, S., Kaushik, R., Kumria, R., Bansal, K., \& Dhawan, S. (2004). Chitosan microspheres as a potential carrier for drugs. International Journal of Pharmaceutics, 274(1-2), 1-33. http://dx.doi.org/10.1016/j.ijpharm.2003.12.026. PMid:15072779.

Soto-Valdez, H., Ezquerra-Brauer, J. M., Márquez-Ríos, E., \& TorresArreola, W. (2015). Effect of previous chilling storage on quality loss in frozen $\left(-20{ }^{\circ} \mathrm{C}\right)$ sierra (Scomberomorus sierra) muscle packed with a low-density polyethylene film containing butylated hydroxytoluene. Food Science and Technology (Campinas.), 35(1), 202-206. http://dx.doi.org/10.1590/1678-457X.6607.

Suárez-Mahecha, H., De Francisco, A., Beirão, L. H., Pardo-Carrasco, S., \& Córtes-Rodríguez, M. (2007). Post mortem loss of texture of fish meat during cold storage. Acta Biológica Colombiana, 12(1), 3-18. Retreived from http://www.scielo.org.co/pdf/abc/v12n1/v12n1a1.pdf

Terzi, G., \& Gucukoglu, A. (2010). Effects of lactic acid and chitosan on the survival of $V$. parahaemolyticus in mussel samples. Journal of Animal and Veterinary Advances, 9(6), 990-994. http://dx.doi. org/10.3923/javaa.2010.990.994.

Tsai, G., Su, E., Chen, H., \& Pan, C. (2002). Antimicrobial activity of shrimp chitin and chitosan from different treatments and applications of fish preservation. Fisheries Science, 68(1), 170-177. http://dx.doi. org/10.1046/j.1444-2906.2002.00404.x.

Tsai, M., Liu, C., Hsu, M., \& Chow, T. (2003). White light emission from single component polymers fabricated by spin coating. Applied Physics Letters, 82(4), 550-552. http://dx.doi.org/10.1063/1.1540247.

Valencia-Perez, A. Z., Soto-Valdez, H., Ezquerra-Brauer, J. M., Márquez-Ríos, E., \& Torres-Arreola, W. (2015). Quality changes during frozen storage of blue shrimp (Litopenaeus stylirostris) with antioxidant, $\alpha$-tocopherol, under different conditions. Food Science and Technology (Campinas.), 35(2), 368-374. http://dx.doi. org/10.1590/1678-457X.6666.

Vatavali, K., Karakosta, L., Nathanailides, C., Georgantelis, D., \& Kontominas, M. G. (2013). Combined effect of chitosan and oregano essential oil dip on the microbiological, chemical, and sensory attributes of red porgy (Pagrus pagrus) stored in ice. Food and Bioprocess Technology, 6(12), 3510-3521. http://dx.doi.org/10.1007/ s11947-012-1034-z.

Veeck, A. P. L., Klein, B., Ferreira, L. F., Becker, A. G., Heldwein, C. G., Heinzmann, B. M., Baldisserotto, B., \& Emanuelli, T. (2013). 
Lipid stability during the frozen storage of fillets from silver catfish exposed in vivo to the essential oil of Lippia alba (Mill.) NE Brown. Journal of the Science of Food and Agriculture, 93(4), 955-960. http:// dx.doi.org/10.1002/jsfa.5833. PMid:22926822.
Woyewoda, A. D., Shaw, S. J., Ke, P. J., \& Burns, B. G. (1986). Recommended laboratory methods for assessment of fish quality. Canadian Technical Report of Fisheries and Aquatic Sciences, 1418, 1-148. Retreived from http://www.dfo-mpo.gc.ca/Library/11897.pdf 